\title{
Simultaneous pollinator occurence (Hymenoptera, Agaoninae) in a threatened species: Ficus mexiae Standley (Moraceae)
}

\author{
Schiffler $^{a, *}$, G., Kloss ${ }^{b}$ TG. and Matos ${ }^{c}, J R$. \\ ${ }^{a}$ Departamento de Biologia Animal, Instituto de Biologia, Universidade Estadual de Campinas - Unicamp, CEP \\ 13083-862, Campinas, São Paulo, Brazil \\ ${ }^{b}$ Centro de Ciências Agrárias, Universidade Federal do Espirito Santo, CEP 29650-000, Alegre, Espírito Santo, Brazil \\ ${ }^{c}$ Faculdade de Ciências Biológicas, Escola Superior São Francisco de Assis - ESFA, CEP 29650-000, Santa Teresa, \\ Espirito Santo, Brazil \\ *e-mail: gustavo.schiffler@gmail.com
}

Received January 3, 2012 - Accepted August 24, 2012 - Distributed August 31, 2013

(With 1 figure)

\begin{abstract}
In Brazil, Ficus mexiae is classified as Vulnerable under IUCN criteria, and to date there is only one report on pollinator activity for this species. Is not unusual to find cases where more than one species of wasp simultaneously occurs on and pollinates the same fig. In this study we present evidence that two Pegoscapus wasp species contribute to the pollination of $F$. mexiae and relationship between pollinators maybe competitive. These results indicate that the $F$. mexiae population represent an important element in the complex dynamics of maintaining diversity in neotropical Ficus spp.
\end{abstract}

Keywords: co-occurrence, pollinators, Pegoscapus, Ficus mexiae.

\section{Ocorrência simultânea de polinizadores (Hymenoptera, Agaoninae) em uma espécie ameaçada: Ficus mexiae Standley (Moraceae)}

\section{Resumo}

No Brasil, Ficus mexiae é classificada como uma espécie vulnerável sob os critérios da IUCN, e até agora não há um único relatório sobre a atividade dos polinizadores desta espécie. Não é raro encontrar casos em que mais de uma espécie de vespa, simultaneamente, ocorre e poliniza o mesmo figo. Neste estudo, apresentamos evidências de que duas espécies de vespas Pegoscapus contribuem para a polinização de F. mexiae, possivelmente em uma relação competitiva. Estes resultados indicam que a população $F$. mexiae representa um elemento importante na dinâmica complexa de manutenção da diversidade de Ficus spp. neotropicais.

Palavras-chave: coocorrência, polinizadores, Pegoscapus, Ficus mexiae.

\section{Introduction}

The Atlantic Forest biodiversity hotspot includes a large number of species of fig, Ficus L. (Moraceae) (Carauta, 1989) that play an important role in providing key resources to many species - provisioning edible fruits, and contributing to the maintenance of faunal diversity (Shanahan et al., 2001). Many Ficus species are threatened with extinction, among them Ficus mexiae Standley that is classified as vulnerable by the International Union for Conservation of Nature and Natural Resources (IUCN, 2011). This is a rare medium-sized plant measuring up to 10 meters in height, which is restricted to Minas Gerais and Bahia (Carauta and Diaz, 2002). Little is known about the reproductive aspects of this plant, although there is one report of two Pegoscapus Cameron (1906) species of fig wasp, simultaneously occurring in its syconiums (Schiffler, 2002).
There are over than 800 known species of Ficus (Moraceae) genus distributed in the tropical and subtropical regions of the world (Harrison, 2005), and for a long time it was believed that each species of fig had only one pollinating species of wasp (Ramirez, 1970; Ramirez, 1974; Wiebes, 1979). It is true for many species, because the fig wasps show a peculiar morphological adaptation, with a high level of phenological synchrony and many are indeed extremely specific about the host (Wiebes, 1979). On the other hand, several cases are reported in which multiple wasp species can act as pollinators for a fig tree, and this may occur from 25 to $50 \%$ all fig species (Cook and Rasplus, 2003; Machado et al., 2005). The simultaneous occurrence of more than one species of wasp that are Ficus pollinators had already been demonstrated by several authors (Rasplus, 1996; Weiblen, 2001; Wieblen, 2002; Vaamonde et al., 2002; Haine et al., 
2006), as well in different continents (Compton et al., 1991; Kerdelhué et al., 1997). However, only one cooccurrence record is known within the South American, between two Pegoscapus (species not yet described) species in Ficus mexiae, without knowing which one is actually the pollinator (Schiffler, 2002). Considering that Pegoscapus sp 1 and Pegoscapus sp 2 possessed pollen in their mesoternary cavities (pollen pockets), Schiffler (2002) proposed the hypothesis that both species play a role in pollinating Ficus mexiae. Based on this information, this work presents preliminary results on Ficus mexiae pollination by Pegoscapus sp 1 and Pegoscapus sp 2 that occurs simultaneously in the plant's syconium.

\section{Material and Methods}

We analyzed 57 syconium collected from two native Ficus mexiae individuals, located in the Universidade Federal de Lavras' campus, in the city of Lavras, state of

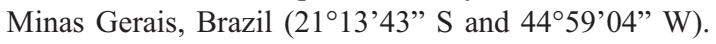
Before collection, the syconiums were individually covered by polyester nets (forming little bags) to retain emerging wasps. The bags were placed on the syconiums on May 14, 2001, and remained there during the time of wasp hatching ( 2 to 3 days). After the hatching, all the material was taken to the laboratory for sorting. Following this the hatching wasps were captured using an entomological aspirator and afterwards packed together with the original syconium, in flasks with a solution of $10 \%$ of formaldehyde. We counted the number of individuals for each wasp species present in each syconium and the number of ovaries with seeds. We also recorded measurements of the syconiums' size and weight. To verify if the data presented Gaussian distribution, the KolmogorovSmirnov's test (Zar, 1974) was applied. Spearman correlation was used to test the correlation between the abundance of Pegoscapus species and the syconium's structural data (Zar, 1974). The difference between the average individual number of Pegoscapus sp 1 and Pegoscapus sp 2 in the syconiums was tested using the Mann-Whitney (U test) (Zar, 1974).

\section{Results and Discussion}

We captured a total of 305 individuals (DP \pm 101 ) of Pegoscapus per syconium, $16 \%$ of which were from Pegoscapus sp 1 and 71\% Pegoscapus sp 2. The Ficus mexiae syconium presented an average size of $15.3 \mathrm{~mm}$ (DP $\pm 1.3 \mathrm{~mm}$ ) and weight of $1.6 \mathrm{~g}$ (DP $\pm 0.3 \mathrm{~g}$ ). As was expected, the heaviest syconiums were also the biggest $\left(\mathrm{r}_{\mathrm{s}}=0.83 ; \mathrm{p}<0.0001\right)$ and the thickest $\left(\mathrm{r}_{\mathrm{s}}=0.50\right.$; $\mathrm{p}<0.01)$. The number of individuals from both Pegoscapus species increased as the syconium increased in size $\left(\mathrm{r}_{\mathrm{s}}=0.27 ; \mathrm{p}<0.05\right)$. This correlation may become stronger when also taking account of the number of non-pollinating wasps. With an increase in the syconium size the production of seeds also increases $\left(r_{s}=0.61\right.$; $\mathrm{p}<0.001$ ), possibly because it aids the entrance of more pollinator wasps (founders). There was a statistically significant correlation between the number of individual Pegoscapus sp 1 and the size of the syconium $\left(\mathrm{r}_{\mathrm{s}}=0.37\right.$; $\mathrm{p}<0.005)$, but the same pattern was not true for Pegoscapus sp 2. The number of individuals of Pegoscapus sp 1 was positively correlated with the number of seeds produced $\left(\mathrm{r}_{\mathrm{s}}=0.48 ; \mathrm{p}<0.0002\right)$, suggesting that it does provide a pollinator function. However, and contrary to what was expected, the most abundant species (Pegoscapus sp 2) did not correlate with the seed production. Yet, in cases where only Pegoscapus sp 1 occurred (7\%) or only Pegoscapus sp 2 (35\%) seed production was recorded, and average size of seeds produced from both was similar ( $U=14.5 ; \mathrm{p}<0.05$; Figure 1$)$, as was their average abundance $(U=17.5 ; p<0.05$; Figure 1). There was no difference between the average abundance of Pegoscapus sp 1 and Pegoscapus sp 2 $(\mathrm{U}=414.5 ; \mathrm{p}<0.05)$, although their pair-wise abundance showed a negative correlation $\left(\mathrm{r}_{\mathrm{s}}=-0.70 ; \mathrm{p}<0.0001\right)$. This evidence of an antagonistic relation between these two Pegoscapus species suggests that these species may compete for ovaries on Ficus mexiae. However, independently of the interaction between these two wasps it provides evidence that both promote the pollination of Ficus mexiae.

One species of Ficus may be host for two or more different pollinator or non pollinator wasp species (Wiebes, 1995), and one pollinator wasp species may have more than one Ficus species as a host (Compton, 1990, Ware and Compton, 1992; Rasplus, 1996). When the host specificity is broken, the process of introgression between figs could occur giving rise to new species, thereby contributing to the increased diversity of figs (Machado et al., 2005).

While preliminary, these results indicate that the $F$. mexiae population besides being maintained by more than one Pegoscapus, and therefore represent an important element in the complex dynamics of maintaining diversity in neotropical Ficus spp.

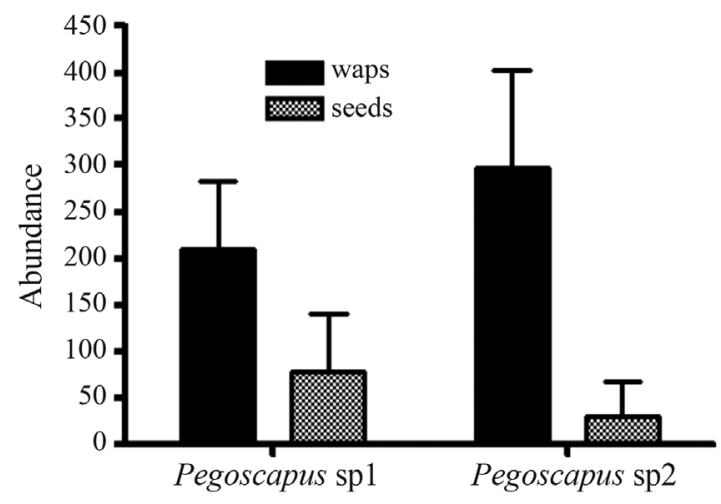

Figure 1 - Average abundance of wasps and seeds per syconium, when only one species of Pegoscapus occurs (error bars represent $\mathrm{SD}$ ). 


\section{Acknowledgments}

We thank the assistance of Dr. Tob Gardner, Cambridge University, UK and Dr. Jos Barlow, Lancaster University, UK in the revision of this manuscript.

\section{References}

CARAUTA, JPP. and Diaz, BE., 2002. Figueiras do Brasil. Rio de Janeiro: Editora UFRJ. 212 p.

CARAUTA, JPP., 1989. Ficus (Moraceae) no Brasil: Conservação e Taxonomia. Albertoa, vol. 2, p. 1-365.

COMPTON, SG., 1990. A collapse of host specificity in some African fig wasps. Society African Journal Science, vol. 86, no.1, p. 39-40.

COMPTON, SG., HOLTON, KC., RASHBROOK, VK., VAN NOORT, S., VINCENT, L. and WARE, AB., 1991. Studies of Ceratosolen galili, a non-pollinating Agaonid fig wasp. Biotropica, vol. 23, p.188-94.

COOK, JM. and RASPLUS, JY., 2003. Mutualists with attitude: coevolving fig wasps and figs. Trends in Ecology \& Evolution, vol. 18, p. 241-248.

HAINE, E., MARTIN, J., and COOK, JM., 2006. Deep mtDNA divergences indicate cryptic species in fig-pollinating wasps. BMC Evolutionary Biology, vol. 6, no. 83. doi:10.1186/1471-2148-6-83.

HARRISON, RD., 2005. Figs and the diversity of tropical rainforests. Bioscience, vol. 55, p. 1053-1064.

IUCN, 2011. IUCN Red List of Threatened Species. Version 2011.2. Available from: www.iucnredlist.org. Access in: 16 nov. 2011.

KERDELHUÉ, C., HOCHBERG, ME. and RASPLUS, J.Y., 1997. Active pollination of Ficus sur by two sympatric fig wasp species in West Africa. Biotropica, vol. 29, p. 69-75.

MACHADO, CA., ROBBINS, N., GILBERT, MTP. and HERRE, EA., 2005. A critical review of host-specificity and its co-evolutionary implications in the fig/fig wasp mutualism. Proceedings of the National Academy of Sciences. vol. 102 (suppl1), p. 6558-6565.
RAMIREZ, WB., 1970. Host specificity of figwasps (Agaonidae). Evolution, vol. 24, p. 680-91.

RAMIREZ, WB., 1974. Coevolution of Ficus and Agaonidae. Annals of the Missouri Botanical Garden, vol. 61, p. $770-80$

RASPLUS, JY., 1996. The one-to-one specificity of the FicusAgaoninae mutualism: howcasual? In VAN DER MAESEN, LJG., VAN DER BURGT, XM., VAN MEDENBACH DE ROOY, JM. (Ed.). The Biodiversity of African Plants. Wageningen: Kluwer Academic Publishers. p. 639-649.

SCHIFFLER, G., 2002. Fig Wasps (Hymenoptera: Agaonidae) associated to Ficus mexiae Standl (Moraceae) in Lavras, Minas Gerais, Brazil. Neotropical Entomology, vol. 31, no. 4 , p. 653-655.

SHANAHAN, M., SO, S., COMPTON, SG. and CORLETT, R., 2001. Fig-eating by vertebrate frugivores: a global review. Biological Reviews, vol. 76, no. 4, p. 529-572.

VAAMONDE, LC., DIXON, DJ, COOK, J. and RASPLUS, JY., 2002. Revision of the Australian species of Pleistodontes (Hymenoptera: Agaonidae) fig-pollinating wasps and their host plant associations. Zoological Journal of the Linnaean Society, vol. 136, p. 637-683.

WARE, AB. and COMPTON, SG., 1992. Breakdown of pollinator specificity in an African Fig Tree, Biotropica, vol. 24, no. 4, p. 544-549.

WEIBLEN, GD., 2001. Phylogenetic relation- ships of fig wasps pollinating function- ally dioecious figs based onmitochondrial DNA sequences and morphology. Systematic Biology, vol. 50, p. 243-67.

WIEBES, JT., 1979. Co-evolution of figs and their insect pollinator. Annual Review of Ecology and Systematics, vol. 10 , p. 1-12.

WIEBES, JT., 1995. The new World Agaoninae (pollinators of figs). Verhandelingen Koninklijke Nederlandse Akademie Wetenschappen Afdeling Natuurkunde. $2^{\text {nd }}$ ed. Wetenschappen. $60 \mathrm{p}$.

WIEBLEN, GD., 2002. How to be a Fig Wasp. Annual Review of Entomology, vol. 47, p. 299-330.

ZAR, JH., 1974. Bioestatistical analysis. Englewood Clifs: Prentice-Hall. 620 p. 